\title{
Actinomadura apis sp. nov., isolated from a honey bee (Apis mellifera) hive, and the reclassification of Actinomadura cremea subsp. rifamycini Gauze et al. 1987 as Actinomadura rifamycini (Gauze et al. 1987) sp. nov., comb. nov.
}

\author{
Yaowanoot Promnuan, ${ }^{1}$ Takuji Kudo, ${ }^{2}$ Moriya Ohkuma ${ }^{2}$ \\ and Panuwan Chantawannakul ${ }^{1}$ \\ ${ }^{1}$ Department of Biology, Faculty of Science, Chiang Mai University, Chiang Mai 50200, Thailand \\ 2 Japan Collection of Microorganisms, RIKEN BioResource Center, 2-1 Hirosawa, Wako, Saitama \\ 351-0198, Japan
}

Correspondence

Panuwan Chantawannakul panuwan@gmail.com

\begin{abstract}
A Gram-reaction-positive aerobic actinomycete, designated strain IM17-1 ${ }^{\top}$, was isolated from a honey bee (Apis mellifera) hive in Chiang Mai Province, Thailand. The strain formed a branched substrate mycelium and mature aerial mycelium bore short chains of arthrospores with warty surfaces. The cell wall contained meso-2,6-diaminopimelic acid (cell-wall type III) and the whole cell sugars were fucose, galactose, glucose, madurose, mannose and ribose. The major isoprenoid quinone was hexahydrogenated menaquinone with nine isoprene units and the predominant cellular fatty acids were $\mathrm{C}_{16: 0}(33.8 \%), \mathrm{C}_{18: 1} \omega 9 \mathrm{c}(32.7 \%)$, summed feature 3 $\left(\mathrm{C}_{16: 1} \omega 7 \mathrm{c}\right.$ and/or iso- $\left.\mathrm{C}_{15: 0} 2-\mathrm{OH}\right)(8.7 \%)$ and 10-methyl $\mathrm{C}_{18: 0}(8.2 \%)$. The phospholipids were diphosphatidylglycerol, phosphatidylinositol and phosphatidylinositol mannosides. These morphological and chemotaxonomic characteristics were consistent with the classification of IM17-1 ${ }^{\top}$ within the genus Actinomadura. Based on 16S rRNA gene sequence analysis, strain IM17-1 ${ }^{\top}$ was closely related to the type strains of Actinomadura cremea subsp. cremea (98.1\%) and Actinomadura cremea subsp. rifamycini (98.6\%); however, it represented a distinct phylogenetic lineage from the other species within this genus. The unique genetic characteristics were reaffirmed by low levels of DNA-DNA relatedness between strain IM1 $7-1^{\top}$ and the two most closely related type strains, $A$. cremea subsp. cremea JCM $3308^{\top}(56.5 \pm 4.9 \%)$ and $A$. cremea subsp. rifamycini JCM $3309^{\top}(31.0 \pm 22.6 \%)$, and further supported the proposal of IM1 $17-1^{\top}$ as a novel species. Strain IM17-1 ${ }^{\top}\left(=\right.$ JCM $16576^{\top}=$ TISTR $\left.1980^{\top}\right)$ thus represents a novel species of the genus Actinomadura, for which the name Actinomadura apis sp. nov. is proposed. In addition, the genotypic and phenotypic data suggested the reclassification of Actinomadura cremea subsp. rifamycini Gauze et al. 1987 as a separate species, Actinomadura rifamycini sp. nov., comb. nov.
\end{abstract}

The genus Actinomadura was established by Lechevalier \& Lechevalier (1968) and, at the time of writing, encompassed 42 species with validly published names including two subspecies, Actinomadura cremea subsp. cremea (Preobrazhenskaya et al., 1975) and Actinomadura cremea subsp. rifamycini (Gauze et al., 1975, 1987) (http://www. bacterio.cict.fr/). Members of this genus are aerobic Grampositive actinomycetes that can grow at $10-60{ }^{\circ} \mathrm{C}$ and form non-fragmenting branched substrate mycelia, which give

The GenBank/EMBL/DDBJ accession numbers for the partial $16 \mathrm{~S}$ rRNA gene sequences of strain $\mathrm{IM} 17-1^{\top}$ and Actinomadura rifamycini JCM $3309^{\top}$ are AB557596 and AB557595, respectively.

A supplementary table is available with the online version of this paper. rise to aerial hyphae bearing spore chains up to 15 spores long with various shapes and ornamentations. Other characteristics of the genus are as follows. The cell-wall peptidoglycan is type III sensu Lechevalier \& Lechevalier (1970) containing meso-diaminopimelic acid ( $\left.\mathrm{A}_{2} \mathrm{pm}\right)$ without glycine; the major isoprenoid quinone is hexahydrogenated menaquinone with nine isoprene units; wholecell hydrolysates mostly contain madurose; the fatty acid profiles are type 3a sensu Kroppenstedt (1985) containing saturated, unsaturated and branched fatty acids plus tuberculostearic acid, with the exception of the thermophilic actinomadurae, which differ in their fatty acid composition; and the phospholipid pattern is type PI sensu Lechevalier et al. (1981), in which no nitrogenous 
phospholipids are present (Kroppenstedt et al., 1990; Kroppenstedt \& Goodfellow, 2006).

Most actinomadurae are widespread in soil (Cook et al., 2005; Kroppenstedt \& Goodfellow, 2006; Ara et al., 2008), a few are found in clinical materials (Yassin et al., 2010) and one was isolated as an endophyte from the leaves of a medicinal plant in China (Qin et al., 2009). During the course of a study on the microflora of the European honey bee (Apis mellifera Linnaeus, 1758) in Thailand, actinomycetes were isolated from honey bee hive materials. Most of the isolates belonged to the genus Streptomyces and some less common isolates were classified as belonging to the genera Nonomuraea and Nocardiopsis. The remaining isolate, strain $\mathrm{IM} 17-\mathrm{1}^{\mathrm{T}}$, was identified as belonging to the genus Actinomadura but could not be classified in any known species (Promnuan et al., 2009). Here, we describe the characterization and classification of strain IM17- $1^{\mathrm{T}}$, which is, to our knowledge, the first member of the genus Actinomadura isolated from a hive of the European honey bee.

The bacterial strain was isolated using the standard dilution plate method on starch-casein agar (Küster \& Williams, 1964) supplemented with $25 \mu \mathrm{g} \mathrm{ml}^{-1}$ each of nystatin and nalidixic acid. After being incubated at $30{ }^{\circ} \mathrm{C}$ for 21 days, the isolate was transferred to, and purified and maintained on, oatmeal agar (International Streptomyces Project Medium 3; ISP 3) (Shirling \& Gottlieb, 1966) supplemented with $0.1 \%$ yeast extract.

The morphological and physiological characteristics of strain IM17- $1^{\mathrm{T}}$ were determined and compared with those of phylogenetically closely related type strains, A. cremea subsp. cremea JCM $3308^{\mathrm{T}}$ and $A$. cremea subsp. rifamycini JCM $3309^{\mathrm{T}}$. The temperature range for growth and $\mathrm{NaCl}$ tolerance were determined by culturing on ISP 3 medium and incubating for 14 days. Carbon utilization and melanoid pigment production were tested using the methods described by Shirling \& Gottlieb (1966). Biomass for chemotaxonomic studies was prepared from cultures grown in yeast extract-malt extract (ISP 2) broth on a rotary shaker for 2-4 weeks at $30{ }^{\circ} \mathrm{C}$. The isomers of $\mathrm{A}_{2} \mathrm{pm}$ were determined by TLC of whole-cell hydrolysates according to the method of Staneck \& Roberts (1974). Reducing sugars in whole-cell hydrolysates were analysed by using the HPLC method of Mikami \& Ishida (1983). Phospholipids were extracted and identified following the methods of Minnikin et al. (1984). Methyl esters of cellular fatty acids were prepared and analysed according to the instructions for the Sherlock Microbial Identification System (version 2.998, MIDI) using GC (model HP6890; Hewlett Packard) with the TSBA40 method (Sasser, 1990). Isoprenoid quinones were extracted according to the method of Collins et al. (1977, 1984) and were analysed in an HPLC system (model LC10AD VP; Shimadzu) equipped with a Cosmosil $5 \mathrm{C}_{18}$ column (Nacalai Tesque) (Tamaoka et al., 1983).

Cultural characteristics of strain IM17- $1^{\mathrm{T}}$ were determined after incubation at $30{ }^{\circ} \mathrm{C}$ for 21 days on various media as described by Shirling \& Gottlieb (1966) and Asano \&
Kawamoto (1986). Determination of colony colours was based on Jacobson et al. (1958). After incubation on ISP 2 and ISP 3 agar at $30{ }^{\circ} \mathrm{C}$ for 21 days, morphological properties were examined using a light microscope and a scanning electron microscope (model S-2400; Hitachi). Samples for scanning electron microscopy were prepared as described by Itoh et al. (1989). Genomic DNA extraction, PCR-mediated amplification of the 16S rRNA gene and sequencing of the PCR products were carried out as described by Nakajima et al. (1999). CLUSTAL_X (Thompson et al., 1997) was used to perform a multiple alignment of sequences downloaded from GenBank and the sequences obtained in this study. The alignment was verified manually and adjusted prior to the reconstruction of a phylogenetic tree. For reconstruction of phylogenetic trees, the software packages MEGA version 4 (Tamura et al., 2007) and CLUSTAL_X were used. Phylogenetic trees were reconstructed using the neighbour-joining (Saitou \& Nei, 1987), minimum-evolution and maximum-parsimony methods (Takahashi \& Nei, 2000), based on a comparison of $1172 \mathrm{nt}$ present in all of the strains after elimination of gaps and ambiguous nucleotides from the sequences corresponding to positions 34 and 1491 in Escherichia coli. Streptosporangium album DSM $43023^{\mathrm{T}}$ was used as an outgroup. Confidence values for the branches of the phylogenetic tree were determined using bootstrap analysis based on 1000 resamplings (Felsenstein, 1985). Sequence similarities between strains of the genus Actinomadura were calculated manually after pairwise alignment was performed using CLUSTAL_X.

For preparation of chromosomal DNA for $\mathrm{G}+\mathrm{C}$ content analysis and DNA-DNA hybridization experiments, cells were freeze-dried and mechanically ground as described by Reader \& Broda (1985). The G $+\mathrm{C}$ content of the DNA was determined using the HPLC method of Tamaoka \& Komagata (1984). An equimolar mixture of nucleotides for analysis of the DNA base composition (Yamasa Shoyu) was digested by bacterial alkaline phosphatase and used as the quantitative standard. Levels of DNA-DNA relatedness were measured fluorometrically using the microplate hybridization method devised by Ezaki et al. (1989). Hybridization was carried out at $60{ }^{\circ} \mathrm{C}$ for $12 \mathrm{~h}$.

Strain IM17- $1^{\mathrm{T}}$ was found to be a Gram-positive aerobic actinomycete that produced well-developed and branched substrate hyphae. Spore chains were short, curved and consisted of $\sim 3-5$ non-motile spores with warty surfaces. The spores were borne on aerial hyphae as shown in Fig. 1a. The spore morphology was similar to that of A. cremea subsp. rifamycini, the most closely related species, phylogenetically (Fig. 1b).

The cultural characteristics of strain IM17- $1^{\mathrm{T}}$ were also examined. The isolate showed good growth on glucoseyeast extract agar and moderate growth on ISP 2, ISP 3, ISP 4, ISP 5 and ISP 7 media, Bennett agar, glucose-asparagine agar, Hickey-Tresner agar, nutrient agar and oatmealnitrate agar. Strain IM17-1 $1^{\mathrm{T}}$ formed white to grey aerial 


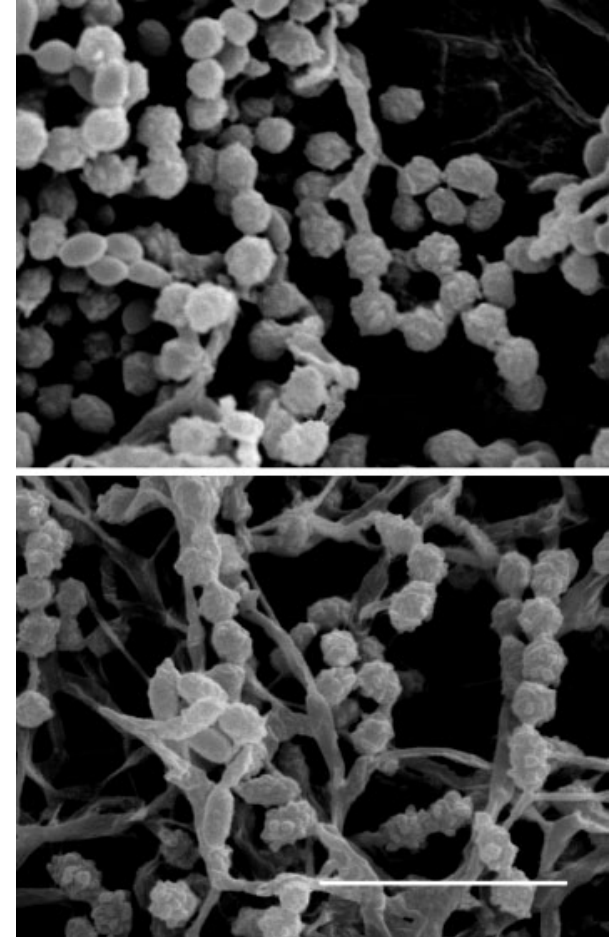

Fig. 1. Scanning electron micrographs showing short chains of arthrospores in strains $1 \mathrm{M} 17-1^{\top}$ (a) and Actinomadura cremea subsp. rifamycini JCM $3309^{\top}$ (b). The cultures were grown on oatmeal agar (ISP 3) with $0.1 \%$ yeast extract at $30{ }^{\circ} \mathrm{C}$ for 3 weeks. Bar, $5 \mu \mathrm{m}$.

mycelia on the various media tested and the substrate mycelia showed different colours on different media (Supplementary Table S1, available in IJSEM Online). A greenish-black pigment was produced on ISP 2 and ISP 7 media. Strain IM17- $1^{\mathrm{T}}$ grew at $20-45^{\circ} \mathrm{C}$, at $\mathrm{pH}$ 6.0-12.0 and in the presence of $4 \%(\mathrm{w} / \mathrm{v}) \mathrm{NaCl}$.

Chemotaxonomic analyses revealed that strain $\mathrm{IM} 17-1^{\mathrm{T}}$ exhibited characteristics that were typical of members of the genus Actinomadura. The cell wall contained meso$\mathrm{A}_{2} \mathrm{pm}$ and whole-cell sugars including fucose, galactose, glucose, madurose, mannose and ribose. The phospholipids were diphosphatidylglycerol, phosphatidylinositol and phosphatidylinositol mannosides. The predominant menaquinones were MK-9 $\left(\mathrm{H}_{6}\right)(53 \%)$ and $\mathrm{MK}-9\left(\mathrm{H}_{8}\right)(26 \%)$; MK-9 $\left(\mathrm{H}_{4}\right)(8 \%)$ was detected as a minor component. The major cellular fatty acids were $\mathrm{C}_{16: 0}(33.8 \%), \mathrm{C}_{18: 1} \omega 9 c$ $(32.7 \%)$, summed feature $3\left(\mathrm{C}_{16: 1} \omega 7 c\right.$ and/or iso- $\mathrm{C}_{15: 0} 2$ $\mathrm{OH})(8.7 \%)$ and 10-methyl $\mathrm{C}_{18: 0}(8.2 \%)$; minor amounts of $\mathrm{C}_{18: 0}(6.9 \%)$, iso- $\mathrm{C}_{16: 0}(1.9 \%), \mathrm{C}_{14: 0}(1.7 \%), \mathrm{C}_{17: 0}$ $(<1 \%)$ and $\mathrm{C}_{16: 1} \omega 9 c(<1 \%)$ were also present (Table 1$)$.

The 16S rRNA gene sequence of strain IM17- $1^{\mathrm{T}}$ (1495 nt) was compared with sequences of all species with validly published names within the genus Actinomadura and related taxa in the family Thermomonosporaceae (Rainey et al., 1997 in Stackebrandt et al., 1997; emend. Zhi et al., 2009). Based on the comparative study of 16 S rRNA gene sequences, strain $\mathrm{IM} 17-1^{\mathrm{T}}$ shared the closest sequence similarity values with $A$. cremea subsp. cremea (98.1\%) and A. cremea subsp. rifamycini (98.6\%). The neighbourjoining tree (Fig. 2) showed that strain IM17-1 ${ }^{\mathrm{T}}$ was a member of the genus Actinomadura and was most closely related to A. cremea subsp. cremea and A. cremea subsp. rifamycini but it was also readily distinguisable from the two subspecies ( $95 \%$ bootstrap support). To confirm the taxonomic position of the isolate, DNA-DNA hybridization studies were carried out. The mean of DNA-DNA relatedness values of strain IM17- $1^{\mathrm{T}}$ with $A$. cremea subsp. cremea $\mathrm{JCM} 3308^{\mathrm{T}}$ and $A$. cremea subsp. rifamycini JCM $3309^{\mathrm{T}}$ were $56.5 \pm 4.9$ and $31.0 \pm 22.6 \%$, respectively. According to the $70 \%$ DNA-DNA relatedness cut-off point recommended for the delineation of bacterial species (Wayne et al., 1987), strain IM17- ${ }^{\mathrm{T}}$ represents a novel species. This assumption was also confirmed by differences in phenotypic characteristics observed between strains IM17- $1^{\mathrm{T}}$, A. cremea subsp. cremea JCM $3308^{\mathrm{T}}$ and $A$. cremea subsp. rifamycini JCM $3309^{\mathrm{T}}$, such as the production of melanoid pigments, the composition of polar lipids, menaquinones, whole-cell sugars and fatty acids, and carbon utilization patterns (Table 1).

On the basis of the cultural, morphological, physiological and chemotaxonomic characteristics, $16 \mathrm{~S}$ rRNA gene sequence similarity and DNA-DNA hybridization results, strain $\mathrm{IM} 17-1^{\mathrm{T}}$ represents a novel species of the genus Actinomadura, for which the name Actinomadura apis sp. nov. is proposed.

A. cremea subsp. rifamycini appeared on validation list no. 23 (Gauze et al., 1987) as a new subspecies and A. cremea subsp. cremea was automatically created by Rule 46 (Howey et al., 1990). Our findings suggested that taxonomic revision of these subspecies is necessary. We found that the level of DNA-DNA relatedness between $A$. cremea subsp. cremea JCM $3308^{\mathrm{T}}$ and A. cremea subsp. rifamycini $\mathrm{JCM} 3309^{\mathrm{T}}$ was $34 \pm 4.2 \%$, which was much lower than the threshold recommended for members of a single genomic species (Wayne et al., 1987). The partial 16S rRNA gene sequence of A. cremea subsp. rifamycini JCM $3309^{\mathrm{T}}$ was also analysed to confirm the previously determined data and to obtain a longer $16 \mathrm{~S}$ rRNA gene sequence. A. cremea subsp. rifamycini JCM $3309^{\mathrm{T}}$ (accession number AB557595) exhibited $98.5 \%$ $16 \mathrm{~S}$ rRNA gene sequence similarity to $A$. cremea subsp. cremea NBRC $14182^{\mathrm{T}}$ (accession number AB462291). These values supported the elevation of $A$. cremea subsp. rifamycini to an independent species (Stackebrandt \& Ebers, 2006). Some phenotypic differences, such as differences in growth at $45{ }^{\circ} \mathrm{C}$ and menaquinone and fatty acid compositions, between the two subspecies are listed in Table 1. These differences were previously documented in a taxonomic revision of the genus Actinomadura based on chemotaxonomic properties (Kroppenstedt et al., 1990). It is evident from the present and previous studies that $A$. cremea subsp. rifamycini $\mathrm{JCM} 3309^{\mathrm{T}}$ merits status as the type strain of a 
Table 1. Characteristics of strain $\mathrm{IM} 17-1^{\top}$ and the type strains Actinomadura cremea subsp. cremea JCM $3308^{\top}$ and $A c t i n o m a d u r a$ cremea subsp. rifamycini JCM $3309^{\top}$

All data are from this study, except where indicated otherwise. Strains: 1 , IM17-1 ${ }^{\mathrm{T}}$; 2, A. cremea subsp. cremea JCM $3308^{\mathrm{T}}$; 3 , A. cremea subsp. rifamycini JCM $3309^{\mathrm{T}}$. +, Positive; (+), moderate; \pm , poor; -, negative; DPG, diphosphatidylglycerol; PG, phosphatidylglycerol; PI, phosphatidylinositol; PIMs, phosphatidylinositol mannosides; Fuc, fucose; Gal, galactose; Glu, glucose; Mad, madurose; Man, mannose and moderate Rib, ribose.

\begin{tabular}{|c|c|c|c|}
\hline Characteristics & 1 & 2 & 3 \\
\hline Number of spores per chain & $3-5$ & $3-8$ & $3-8$ \\
\hline $\begin{array}{l}\text { Diffusible pigment production in ISP } 7 \\
\text { medium }\end{array}$ & + (greenish-black) & - & - \\
\hline $\begin{array}{l}\text { Melanoid pigment production in ISP } 6 \\
\text { medium }\end{array}$ & - & - & + \\
\hline Growth at $45{ }^{\circ} \mathrm{C}$ & + & - & + \\
\hline Polar lipids & DPG, PI, PIMs & DPG, PI, PG* & DPG, PI, PIMs* \\
\hline Menaquinones & $\begin{array}{l}\text { MK-9 }\left(\mathrm{H}_{6}\right)(53 \%), \text { MK-9 }\left(\mathrm{H}_{8}\right) \\
(26 \%), \text { MK-9 }\left(\mathrm{H}_{4}\right)(8 \%)\end{array}$ & $\begin{array}{c}\text { MK-9 }\left(\mathrm{H}_{6}\right)(83 \%), \text { MK-9 }\left(\mathrm{H}_{4}\right) \\
(11 \%), \text { MK-9 }\left(\mathrm{H}_{8}\right)(6 \%)^{*}\end{array}$ & $\begin{array}{l}\text { MK-9 }\left(\mathrm{H}_{8}\right)(41 \%), \text { MK-9 }\left(\mathrm{H}_{6}\right) \\
\quad(39 \%), \text { MK-9 }\left(\mathrm{H}_{10}\right)(5 \%)\end{array}$ \\
\hline \multicolumn{4}{|l|}{ Fatty acids $(\%)$ : } \\
\hline $\mathrm{C}_{14: 0}$ & 1.7 & 3.9 & 2.5 \\
\hline $\mathrm{C}_{16: 0}$ & 33.8 & 41.2 & 40.9 \\
\hline $\mathrm{C}_{17: 0}$ & $<1$ & $<1$ & 1.3 \\
\hline $\mathrm{C}_{18: 0}$ & 6.9 & 4.3 & 4.0 \\
\hline $\mathrm{C}_{16: 1} \omega 9 c$ & $<1$ & 1.1 & $<1$ \\
\hline $\mathrm{C}_{18: 1} \omega 9 c$ & 32.7 & 14.6 & 25.6 \\
\hline iso- $\mathrm{C}_{16: 0}$ & 1.9 & 1.8 & 2.3 \\
\hline 10-Methyl $\mathrm{C}_{18: 0}$ & 8.2 & 13.4 & 9.4 \\
\hline Summed feature $3 \dagger$ & 8.7 & 16.3 & 9.3 \\
\hline Cell-wall sugars & Fuc, Gal, Glu, Mad, Man, Rib & Gal, Mad, Man, Rib* & Gal, Mad, Man, Rib* \\
\hline DNA G + C content $(\mathrm{mol} \%)$ & 73.7 & $75.1^{\star}$ & 74.5 \\
\hline \multicolumn{4}{|l|}{ Utilization of: } \\
\hline L-Arabinose & \pm & - & $(+)$ \\
\hline Sucrose & - & \pm & \pm \\
\hline Inositol & - & \pm & \pm \\
\hline Rhamnose & \pm & \pm & \pm \\
\hline D-Xylose & - & $\pm 1-$ & $\pm 1-$ \\
\hline
\end{tabular}

${ }^{*}$ Data from Kroppenstedt et al. (1990).

$\dagger$ Summed feature 3 comprises $\mathrm{C}_{16: 1} \omega 7 \mathrm{c}$ and/or iso- $\mathrm{C}_{15: 0}$ 2-OH.

novel species of the genus Actinomadura, for which the name Actinomadura rifamycini sp. nov., comb. nov. is proposed.

\section{Description of Actinomadura apis sp. nov.}

Actinomadura apis (a'pis. L. gen. apis of/from a honey bee, the genus name of the true honey bee Apis mellifera (Linnaeus, 1758), a hive of which was the source of the type strain).

Cells are aerobic Gram-reaction-positive actinomycetes that form a branched substrate mycelium. Aerial mycelium at maturity forms short branched spore chains with 3-5 spores. Spore shape is oval and the spore surface is warty at maturity. On ISP 2 agar, colonies are lacking in aerial mycelia and have a cartilaginous appearance. Good growth occurs on glucoseyeast extract agar and moderate growth occurs on ISP 2, 3, 4, 5 and 7 media, Bennett agar, glucose-asparagine agar,
Hickey-Tresner agar, oatmeal-nitrate agar and nutrient agar. Substrate mycelia are dark-olive to light-brown on various agar media. Aerial mycelia and sporulation are found on ISP3, 4, 5 and 7 media, Hickey-Tresner agar and oatmealnitrate agar. A soluble greenish-black pigment is produced on ISP 2 and ISP 7 media. Growth occurs at $20-45{ }^{\circ} \mathrm{C}$ and pH 6-12 and moderate growth occurs in the presence of $4 \%$ (w/v) $\mathrm{NaCl}$. D-Glucose, L-arabinose and rhamnose are utilized as sole carbon sources but sucrose, D-xylose, inositol, D-mannitol, D-fructose and raffinose are not. Negative for the production of melanoid pigments. The dominant diaminopimelic acid isomer in the cell wall is meso-2,6diaminopimelic acid. Fucose, galactose, glucose, madurose, mannose and ribose occur in whole-cell hydrolysates. Polar lipids detected include diphosphatidylglycerol, phosphatidylinositol and phosphatidylinositol mannosides. The major menaquinones are MK-9 $\left(\mathrm{H}_{6}\right)$ and MK- $9\left(\mathrm{H}_{8}\right)$; minor amounts of MK- $9\left(\mathrm{H}_{4}\right)$ are also present. The fatty acid profile 


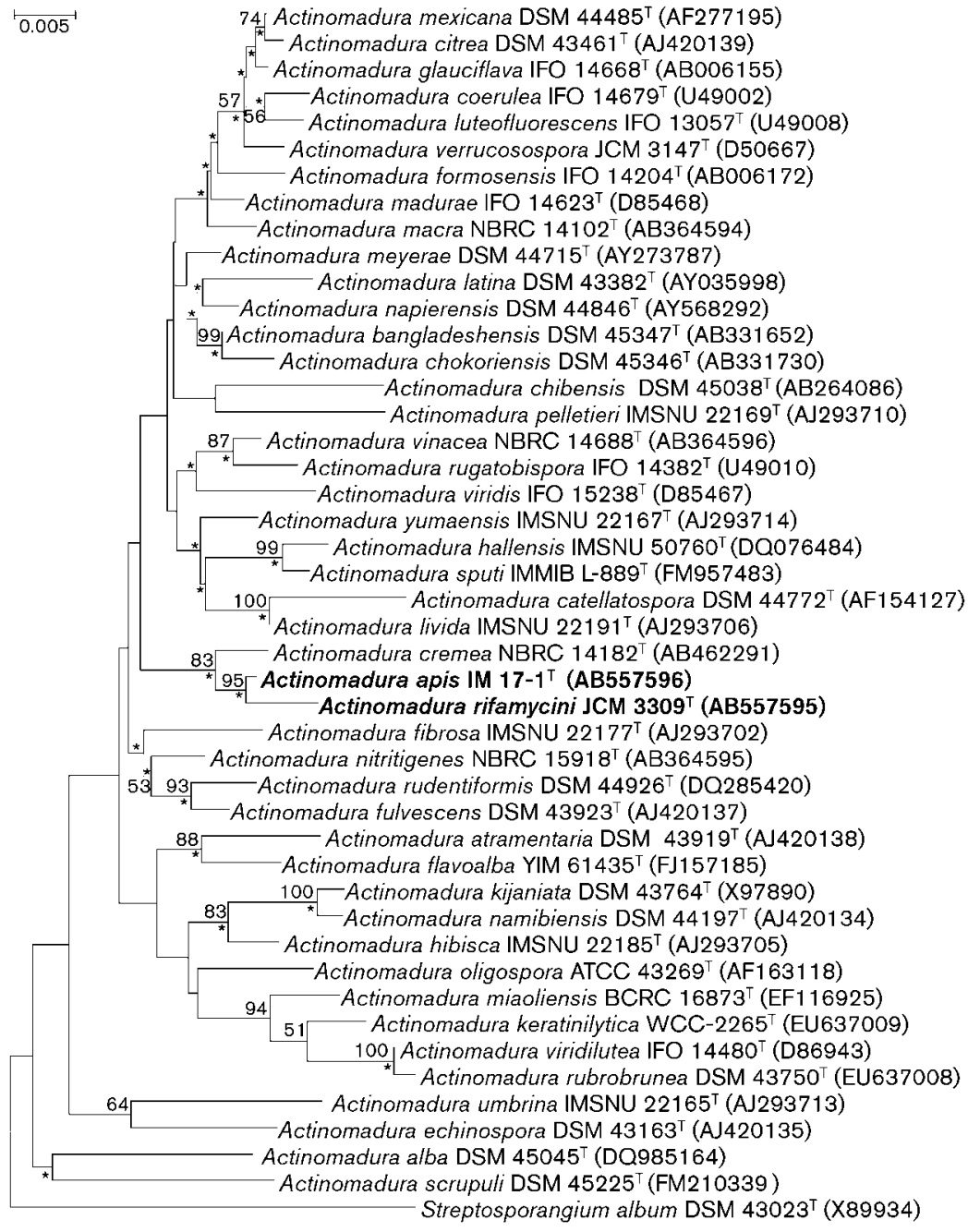

Fig. 2. Neighbour-joining tree based on nearly complete 16S rRNA gene sequences (1172 nt) showing the relationship between strain $\mathrm{IM} 17-1^{\top}$ and the type strains of closely related species of the genus Actinomadura. Streptosporangium album DSM $43023^{\top}$ was used as an outgroup. Bootstrap values $>50 \%$ (based on 1000 replications) are given at nodes. Asterisks indicate the clades that were conserved when the maximum-parsimony and minimum-evolution methods were used to construct phylogenetic trees. Bar, 0.005 substitutions per nucleotide position. is characterized by the presence of significant amounts (>7\% of the total) of $\mathrm{C}_{16: 0}, \mathrm{C}_{18: 1} \omega 9 c$, summed feature 3 $\left(\mathrm{C}_{16: 1} \omega 7 c\right.$ and/or iso- $\left.\mathrm{C}_{15: 0} 2-\mathrm{OH}\right)$ and $10-$ methyl $\mathrm{C}_{18: 0}$.

The type strain, IM17- $1^{\mathrm{T}}$ (=JCM $16576^{\mathrm{T}}=\mathrm{TISTR} 1980^{\mathrm{T}}$ ), was isolated from a honey bee (Apis mellifera) hive in Chiang Mai Province, Thailand. The DNA G $+\mathrm{C}$ content of the type strain is $73.7 \mathrm{~mol} \%$.

\section{Description of Actinomadura rifamycini (Gauze et al. 1987) sp. nov., comb. nov.}

Actinomadura rifamycini (ri.fa.my.ci'ni. N.L. gen. n. rifamycini of rifamycin, referring to an antibiotic, rifamycin).

Basonym: Actinomadura cremea subsp. rifamycini. Gauze et al. 1987.

Forms branched substrate mycelia. Aerial mycelia at maturity form short spore chains with 3-8 spores per chain. Spore shape is oval and the spore surface is warty.

Good growth occurs on ISP 2 medium; poor growth on ISP 3 and 4 media. Substrate mycelia are brown on ISP 2 medium and colourless on ISP 3 and 4 media. Aerial mycelia are white to pale-pink and sporulation occurs in ISP 2, 3 and 4 media. A soluble brown pigment is produced in ISP 2 medium. Growth occurs at $20-50{ }^{\circ} \mathrm{C}$ and $\mathrm{pH} 6-$ 12 ; moderate growth occurs in the presence of $4 \%(\mathrm{w} / \mathrm{v})$ $\mathrm{NaCl}$. D-Glucose, L-arabinose, sucrose, inositol and rhamnose are utilized as sole carbon sources but D-mannitol, Dfructose, D-xylose and raffinose are not. Production of melanoid pigments is positive only in ISP 6 medium after 4 days of growth. The dominant diaminopimelic acid isomer in the cell wall is meso-2,6-diaminopimelic acid. Galactose, madurose, mannose and ribose occur in whole-cell hydrolysates. Polar lipids detected include diphosphatidylglycerol, phosphatidylinositol and phosphatidylinositol mannosides. The major menaquinones are MK-9 $\left(\mathrm{H}_{8}\right)$ and MK-9 $\left(\mathrm{H}_{6}\right)$; minor amounts of MK-9 $\left(\mathrm{H}_{10}\right)$ are also found. The fatty acid profile is characterized by the presence of significant amounts $(>7 \%$ of the total) of $\mathrm{C}_{16: 0}, \mathrm{C}_{18: 1} \omega 9 c, 10$-methyl $\mathrm{C}_{18: 0}$ and summed feature 3 $\left(\mathrm{C}_{16: 1} \omega 7 c\right.$ and/or iso- $\left.\mathrm{C}_{15: 0} 2-\mathrm{OH}\right)$.

The type strain is JCM $3309^{\mathrm{T}}\left(=\right.$ ATCC $33264^{\mathrm{T}}=\mathrm{DSM}$ $43936^{\mathrm{T}}=$ INA $1349^{\mathrm{T}}=\mathrm{KCTC} 9248^{\mathrm{T}}=\mathrm{NBRC} 14183^{\mathrm{T}}$ 
$=$ NCIMB $12768^{\mathrm{T}}=$ NRRL B $-16122^{\mathrm{T}}=\mathrm{VKM} \mathrm{Ac}-1085^{\mathrm{T}}$ ). The $\mathrm{G}+\mathrm{C}$ content of the DNA of the type strain is $74.5 \mathrm{~mol} \%$. The type strain produces rifamycin.

\section{Acknowledgements}

Y.P. was supported by a $\mathrm{PhD}$ grant under the Strategic Scholarships for Frontier Research Network program and the Thai Doctoral degree program from the Office of the Higher Education Commission and the Graduate School, Chiang Mai University. P.C. would like to acknowledge the Thailand Research Fund (RSA5280010), the Hitachi Scholarship Foundation and the Office of the Higher Education Commission for financial support. We also thank Dr Maki Kitahara for her help in providing information and suggestions on DNA-DNA hybridization.

\section{References}

Ara, I., Matsumoto, A., Bakir, M. A., Kudo, T., Omura, S. \& Takahashi, Y. (2008). Actinomadura bangladeshensis sp. nov. and Actinomadura chokoriensis sp. nov. Int J Syst Evol Microbiol 58, 1653-1659.

Asano, K. \& Kawamoto, I. (1986). Catellatospora, a new genus of the Actinomycetales. Int J Syst Bacteriol 36, 512-517.

Collins, M. D., Pirouz, T., Goodfellow, M. \& Minnikin, D. E. (1977). Distribution of menaquinones in actinomycetes and corynebacteria. J Gen Microbiol 100, 221-230.

Collins, M. D., Faulkner, M. \& Keddie, R. M. (1984). Menaquinone composition of some spore forming actinomycetes. Syst Appl Microbiol 5, 20-29.

Cook, A. E., Roes, M. \& Meyers, P. R. (2005). Actinomadura napierensis sp. nov., isolated from soil in South Africa. Int J Syst Evol Microbiol 55, 703-706.

Ezaki, T., Hashimoto, Y. \& Yabuuchi, E. (1989). Fluorometric deoxyribonucleic acid-deoxyribonucleic acid hybridization in microdilution wells as an alternative to membrane filter hybridization in which radioisotopes are used to determine genetic relatedness among bacterial strains. Int J Syst Bacteriol 39, 224-229.

Felsenstein, J. (1985). Confidence limits on phylogenies: an approach using the bootstrap. Evolution 39, 783-791.

Gauze, G. F., Preobrazhenskaia, T. P., Lavrova, N. V., Ukholina, R. S. \& Kochetkova, N. V. (1975). [Actinomadura cremea var. rifamycini, a producer of rifamycin O]. Antibiotiki 20, 963-966 (in Russian).

Gauze, G. F., Terekhova, L. P., Galatenko, O. A., Preobrazhenskaya, T. P., Borisova, V. N. \& Federova, G. B. (1987). Actinomadura cremea subsp. rifamicini subsp. nov. In Validation of the publication of new names and new combinations previously effectively published outside the IJSB: List no. 23. Int J Syst Bacteriol 37, 179-180.

Howey, R. T., Lock, C. M. \& Moore, L. V. H. (1990). Subspecies names automatically created by Rule 46. Int J Syst Bacteriol 40, 317-319.

Itoh, T., Kudo, T., Parenti, F. \& Seino, A. (1989). Amended description of the genus Kineosporia, based on chemotaxonomic and morphological studies. Int J Syst Bacteriol 39, 168-173.

Jacobson, E., Grauville, W. C. \& Fogs, C. E. (1958). Color Harmony Manual, 4th edn. Chicago: Container Corporation of America.

Kroppenstedt, R. M. (1985). Fatty acid and menaquinone analysis of actinomycetes and related organisms. In Chemical Methods in Bacterial Systematics, pp. 173-199. Edited by M. Goodfellow \& D. E. Minnikin. London: Academic Press, Ltd.

Kroppenstedt, R. M. \& Goodfellow, M. (2006). The family Thermomonosporaceae: Actinocorallia, Actinomadura, Spirillospora and Thermomonospora. In The Prokaryotes, 3rd edn, vol. 3, pp. 682724. Edited by M. Dworkin, S. Falkow, E. Rosenberg, K.-H. Schleifer \& E. Stackebrandt. New York, NY: Springer.

Kroppenstedt, R. M., Stackebrandt, E. \& Goodfellow, M. (1990). Taxonomic revision of the actinomycete genera Actinomadura and Microtetraspora. Syst Appl Microbiol 13, 148-160.

Küster, E. \& Williams, S. T. (1964). Selection of media for isolation of streptomycetes. Nature 202, 928-929.

Lechevalier, H. A. \& Lechevalier, M. P. (1968). A critical evaluation of the genera of aerobic actinomycetes. In The Actinomycetales, pp. 393405. Edited by H. Prauser. Jena: VEB Gustav Fischer Verlag.

Lechevalier, M. P. \& Lechevalier, H. A. (1970). Chemical composition as a criterion in the classification of aerobic actinomycetes. Int J Syst Bacteriol 20, 435-443.

Lechevalier, M. P., Stern, A. E. \& Lechevalier, H. A. (1981). Phospholipids in the taxonomy of actinomycetes. Zentralbl Bakteriol Microbiol Hyg Abt 1 (Suppl 11), 111-116.

Mikami, H. \& Ishida, Y. (1983). Post-column fluorometric detection of reducing sugar in high-performance liquid chromatography using arginine. Bunseki Kagaku 32, E207-E210.

Minnikin, D. E., O'Donnell, A. G., Goodfellow, M., Alderson, G., Athalye, M., Schaal, A. \& Parlett, J. H. (1984). An integrated procedure for the extraction of bacterial isoprenoid quinones and polar lipids. J Microbiol Methods 2, 233-241.

Nakajima, Y., Kitpreechavanich, V., Suzuki, K. \& Kudo, T. (1999). Microbispora corallina sp. nov., a new species of the genus Microbispora isolated from Thai soil. Int J Syst Bacteriol 49, 17611767.

Preobrazhenskaya, T. P., Lavrova, N. V., Ukholina, R. S. \& Nechaeva, N. P. (1975). [Isolation of new species of the genus Actinomadura on selective media with streptomycin and bruneomycin]. Antibiotiki 20, 404-409 (in Russian).

Promnuan, Y., Kudo, T. \& Chantawannakul, P. (2009). Actinomycetes isolated from beehives in Thailand. World J Microbiol Biotechnol 25, 1685-1689.

Qin, S., Zhao, G. Z., Li, J., Zhu, W. Y., Xu, L. H. \& Li, W. J. (2009). Actinomadura flavalba sp. nov., an endophytic actinomycete isolated from leaves of Maytenus austroyunnanensis. Int J Syst Evol Microbiol 59, 2453-2457.

Reader, U. \& Broda, P. (1985). Rapid preparation of DNA from filamentous fungi. Lett Appl Microbiol 1, 17-20.

Saitou, N. \& Nei, M. (1987). The neighbor-joining method: a new method for reconstructing phylogenetic trees. Mol Biol Evol 4, 406425.

Sasser, M. (1990). Identification of bacteria by gas chromatography of cellular fatty acids, MIDI Technical Note 101. Newark, DE: MIDI Inc.

Shirling, E. B. \& Gottlieb, D. (1966). Methods for characterization of Streptomyces species. Int J Syst Bacteriol 16, 313-340.

Stackebrandt, E. \& Ebers, J. (2006). Taxonomic parameters revisited: tarnished gold standards. Microbiol Today 33, 152-155.

Stackebrandt, E., Rainey, F. A. \& Ward-Rainey, N. L. (1997). Proposal for a new hierarchic classification system, Actinobacteria classis nov. Int J Syst Bacteriol 47, 479-491.

Staneck, J. L. \& Roberts, G. D. (1974). Simplified approach to identification of aerobic actinomycetes by thin-layer chromatography. Appl Microbiol 28, 226-231.

Takahashi, K. \& Nei, M. (2000). Efficiencies of fast algorithms of phylogenetic inference under the criteria of maximum parsimony, minimum evolution, and maximum likelihood when a large number of sequences are used. Mol Biol Evol 17, 1251-1258. 
Tamaoka, J. \& Komagata, K. (1984). Determination of DNA base composition by reversed-phase high-performance liquid chromatography. FEMS Microbiol Lett 25, 125-128.

Tamaoka, J., Katayama-Fujimura, Y. \& Kuraishi, H. (1983). Analysis of bacterial menaquinone mixtures by high-performance liquid chromatography. J Appl Microbiol 54, 31-36.

Tamura, K., Dudley, J., Nei, M. \& Kumar, S. (2007). MEGA4: molecular evolutionary genetics analysis (MEGA) software version 4.0. Mol Biol Evol 24, 1596-1599.

Thompson, J. D., Gibson, T. J., Plewniak, F., Jeanmougin, F. \& Higgins, D. G. (1997). The CLUSTAL_X windows interface: flexible strategies for multiple sequence alignment aided by quality analysis tools. Nucleic Acids Res 25, 4876-4882.
Wayne, L. G., Brenner, D. J., Colwell, R. R., Grimont, P. A., Kandler, O., Krichevsky, M. I., Moore, L. H., Moore, W. E. C., Murray, R. G. E. \& other authors (1987). International Committee on Systematic Bacteriology. Report of the ad hoc committee on reconciliation of approaches to bacterial systematics. Int J Syst Bacteriol 37, 463-464.

Yassin, A. F., Spröer, C., Siering, C. \& Klenk, H.-P. (2010). Actinomadura sputi sp. nov., isolated from the sputum of a patient with pulmonary infection. Int J Syst Evol Microbiol 60, 149-153.

Zhi, X. Y., Li, W. J. \& Stackebrandt, E. (2009). An update of the structure and 16S rRNA gene sequence-based definition of higher ranks of the class Actinobacteria, with the proposal of two new suborders and four new families and emended descriptions of the existing higher taxa. Int J Syst Evol Microbiol 59, 589-608. 